\title{
SPERM PENETRATION OF PIG EGGS IN UTERO
}

\author{
R. D. BAKER* AND G. POLGE \\ ARC Unit of Reproductive Physiology and Biochemistry, \\ 307 Huntingdon Road, Cambridge
}

(Received 14th December 1972)

\begin{abstract}
Summary. Boar spermatozoa fertilized only a small proportion of the follicular and ovulated eggs that were transferred into the uterus of artificially inseminated gilts. The possibility that spermatozoa had entered the oviduct or were influenced by tubal secretions before penetration cannot be excluded. Sperm penetration in utero was not observed when oviducts were ligated at the uterotubal junction before transferring eggs into the uterus.
\end{abstract}

Fertilization of mammalian eggs normally takes place in the ampullary region of the oviduct, but the uterus is known to contribute to fertilization in at least three ways: it contracts to help move spermatozoa from the area of deposition towards the site of fertilization; it provides a milieu for the survival of spermatozoa; and it may play a rôle in capacitation. In the pig, spermatozoa are rapidly transported through the uterine horns to the uterotubal junction (Du Mesnil du Buisson \& Dauzier, 1955; Mann, Polge \& Rowson, 1956; Baker \& Degen, 1972) and high concentrations of spermatozoa persist in reservoirs near the uterotubal junction for up to $72 \mathrm{hr}$ after insemination (Du Mesnil du Buisson \& Dauzier, 1955; Rigby, 1966). However, the relative importance of the uterus and oviduct in capacitating boar spermatozoa has not been investigated. Rabbit spermatozoa can be fully capacitated in the uterus (Chang, 1955; Bedford, 1969) or oviduct (Adams \& Chang, 1962), but surgical separation of the uterus from the oviduct delayed capacitation in the uterus (Bedford, 1969). In contrast to the rabbit, hamster eggs were not observed to be fertilized in the uterus (Hunter, 1968), and it was inferred that hamster spermatozoa require exposure to the tubal environment before they acquire the ability to fertilize.

The present study was conducted to determine if boar spermatozoa would fertilize pig eggs in the uterus. Oestrus in thirty-four cyclic gilts was synchronized according to the system reported by Polge, Day \& Groves (1968). The females received a meal ration containing $100 \mathrm{mg}$ methallibure (AImax, ICI Ltd) for 19 to 21 days, followed by injections of 1000 i.u. PMSG (Organon Ltd) and 500 i.u. HCG (Burroughs Wellcome Ltd) on the 1st and 4th days, respectively, following withdrawal of methallibure. Eleven gilts were ovariectomized 37 to $39 \mathrm{hr}$ after the HCG injection and 164 follicular eggs were recovered from 169 preovulatory follicles ( 7 to $10 \mathrm{~mm}$ in diameter). All the eggs were

* Present address: Department of Animal Science, Macdonald Ciampus of McGill University, Ste Anne de Bellevue, Quebec, Canada. 
surrounded by a sticky mass of cumulus cells typical of those found just before ovulation; $90 \%$ of thirty such eggs fixed as controls contained a first polar body and chromosomes arranged at metaphase of the second meiotic spindle. Oviducts of another eleven females were flushed with warm Tyrode's solution 42 to $46 \mathrm{hr}$ after the HCG injection to recover eggs. Of the $122(74 \%)$ ovulated eggs recovered, $47(38 \%)$ had associated cumulus cells.

Totals of 134 follicular eggs and 105 ovulated eggs were transferred into carbon-marked and unmarked uterine horns, respectively, of twelve oestrous females near the time of ovulation. All twelve gilts were artificially inseminated

Table 1. Effect of tubal and uterine ligation 4 to $12 \mathrm{hr}$ after intracervical insemination and 1 to $2 \mathrm{hr}$ before ovulation on recovery and sperm penetration of alien (uterine) and native (tubal) eggs

\begin{tabular}{l|c|cc|c|c}
\hline & $\begin{array}{c}\text { No. of uterine } \\
\text { horns and oviducts } \\
\text { flushed }\end{array}$ & $\begin{array}{c}\text { Eggs } \\
\text { recovered } \\
(\text { No.) }\end{array}$ & $\begin{array}{c}\text { Penetrated } \\
\text { eggs } \\
(\%)\end{array}$ & $\begin{array}{c}\text { Sperm. attached to } \\
\text { eggs (av. no. } \\
\text { uterine horn or } \\
\text { oviduct }\end{array}$ \\
\hline $\begin{array}{l}\text { Ligated oviducts } \dagger \\
\text { Alien eggs }\end{array}$ & 6 & 22 & 46 & 0 & 2 \\
$\quad$ Native eggs & 6 & 44 & 73 & $52^{*}$ & $93^{*}$ \\
$\begin{array}{l}\text { Non-ligated oviducts } \dagger \\
\text { Alien eggs }\end{array}$ & 6 & 40 & 73 & 2 & 14 \\
$\quad$ Native eggs & 6 & 56 & 92 & 100 & 1572 \\
$\begin{array}{l}\text { Ligated uterine horns } \\
\text { Alien eggs }\end{array}$ & 6 & 40 & 61 & $0 \ddagger$ & $0 \ddagger$ \\
$\quad$ Native eggs & 6 & 55 & 93 & 53 & 621 \\
$\quad \begin{array}{l}\text { Non-ligated uterine horns } \\
\text { Alien eggs }\end{array}$ & 6 & 53 & 76 & 42 & 162 \\
$\quad$ Native eggs & 6 & 62 & 97 & 65 & 395 \\
\hline
\end{tabular}

* Significantly $(P<0.05)$ different from native eggs recovered from non-ligated oviduct.

$\dagger$ Left oviduct was ligated and right oviduct was not ligated.

$\ddagger$ Significantly $(P<0 \cdot 05)$ different from alien eggs from non-ligated uterine horns.

through the cervix with 100 to $150 \mathrm{ml}$ fresh whole semen 4 to $12 \mathrm{hr}$ before the transfer. At the time of the transfer, the left oviduct was ligated at the uterotubal junction in six gilts and both uterine horns were ligated approximately $20 \mathrm{~cm}$ from the uterotubal junction in three of the six remaining females. The gilts were killed 18 to $24 \mathrm{hr}$ after the transfer. Their reproductive tracts were removed immediately after bleeding the carcass. Uterine horns and oviducts were flushed with Tyrode's solution to recover the alien and native eggs, respectively. The eggs were examined for sperm penetration into the zonae, fixed for $24 \mathrm{hr}$ in $25 \%$ acetic alcohol, stained with $1 \%$ aceto-orcein and re-examined.

Only twenty-one follicular and two ovulated eggs recovered from the uterine horns had been penetrated by spermatozoa. None of these penetrated alien eggs was recovered from a uterine horn adjoining a ligated oviduct (Table 1). All but two of the native eggs, however, were recovered from oviducts of the four gilts which contained the fertilized alien eggs, which strongly supports the assumption that the twenty-three penetrated eggs recovered from the uteri were of transfer origin.

All of the alien eggs that were penetrated by spermatozoa in the uterus were 
completely surrounded by masses of sticky cumulus cells at the time of transfer. This observation, plus observations that ovulated eggs without cumulus attached at the time of transfer were not penetrated, and that penetration did not occur in uteri when the oviduct was ligated, support earlier reports (Yanagimachi \& Chang, 1963; Barros \& Austin, 1967) that ovarian follicular fluid contains agents responsible for inducing the acrosome reaction in spermatozoa.

Ligating the oviduct before ovulation significantly $(P<0.05)$ reduced the percentage of native eggs that were penetrated and also the number of spermatozoa observed on their zonae. Tubal ligation also appeared to reduce the number of eggs recovered, but the series of observations was too small to demonstrate significance.

Ligating the uterine horns had no effect on the percentage of native eggs penetrated, on the number of spermatozoa associated with native eggs, or on the percentage of eggs recovered from the oviduct or uterus. The latter observation indicates that the relatively low percentage $(62 \%)$ of alien eggs recovered from the uterus was not due to loss of eggs through the cervix.

None of the alien eggs recovered from the ligated uteri were penetrated by spermatozoa. Flushing fluids from two of the three gilts with ligated horns contained noticeably high concentrations of leucocytes. The other gilt with ligated uterine horns, and one gilt without ligations, had no spermatozoa on either the alien or native eggs or in the flushing fluids. Inseminations in these two gilts were assumed to have been faulty.

Evidence for a delay in the time of penetration of eggs transferred into the uterus of the pig was not observed. The earliest that eggs were examined was $18 \mathrm{hr}$ after transfer. Fourteen of the follicular eggs penetrated in utero had reached the same stage of development, late pronuclear, as native tubal eggs from the same female. Furthermore, thirteen of the alien eggs penetrated in utero were polyspermic with up to four accessory male pronuclei.

One author (R.D.B.) was supported by a Lalor Foundation Research Award. The authors would like to express their thanks to Dr R. H. F. Hunter and $\mathrm{Mr} \mathrm{K}$. Elsome for assistance during surgery.

\section{REFERENGES}

Adams, C. E. \& Ghang, M. C. (1962) Capacitation of rabbit spermatozoa in the Fallopian tube and in the uterus. F. exp. Zool. 151, 159.

BAKER, R. D. \& DEgen, A. A. (1972) Transport of live and dead boar spermatozoa within the reproductive tract of gilts. F. Reprod. Fert. 28, 369.

Barros, C. \& Austin, C. R. (1967) In vitro fertilization and the sperm acrosome reaction in the hamster. J. exp. Zool. 166, 317.

BEDford, J. M. (1969) Limitations of the uterus in the development of the fertilizing ability (capacitation) of spermatozoa. J. Reprod. Fert. Suppl. 8, 19.

Chang, M. G. (1955) Development of fertilizing capacity of rabbit spermatozoa in the uterus. Nature, Lond. 175, 1036.

Du Mesnil du Buisson, F. \& Dauzier, L. (1955) Distribution et résorption du sperme dans le tractus génital de la truie: survie des spermatozoïdes. Annls Endocr. 16, 413.

Hunter, R. H. F. (1968) Attempted fertilization of hamster eggs following transplantation into the uterus. F. exp. Zool. 168, 511.

Mann, T., Polge, G. \& Rowson, L. E. A. (1956) Participation of seminal plasma in the passage of spermatozoa through the female reproductive tract. $\mathcal{F}$. Endocr. 13, 133. 
Polge, C., Day, B. N. \& Groves, T. W. (1968) Synchronization of ovulation and artificial insemination in pigs. Vet. Rec. 83, 136.

Rigby, J. P. (1966) The persistence of spermatozoa at the uterotubal junction of the sow. J. Reprod. Fert. 11, 153.

Yanagimachi, R. \& Chanc, M. C. (1963) Fertilization of hamster eggs in vitro. Nature, Lond. 200, 281. 